Neuroendocrinology 1973;12:I-IV

Contents, Vol. 12, 1973

\title{
Neuroendocrine Relationships
}

Editor-in-Chief: $\quad$ KM. Knigge, Rochester, N.Y.

Editorial Board: I. Assenmacher, Montpellier H. Bern, Berkeley, Calif.

A. Brodish, Cincinnati, Ohio

V. Critchlow, Portland, oreg.

S.A. D'Angelo, Philadelphia, Pa.

P.M. Daniel, London

$B$.

E. Endröczi, Budapest

Donovan, London

W. Etkin, Bronx, N.Y.

J. Flament-Durand, Brussels

B. Flerkó, Pécs

R. Gorski, Los Angeles, Calif.

W.H. Florsheim, Long Beach, Calif.

M.A. Greer, Portland, Oreg.

C.E. Grosvenor, Memphis, Tenn. 
J.R. Hodges, London

T. Hòkfelt, Stockholm

J. W. Kendall, Portland, Oreg.

D. Klein, Bethesda, Md.

H. Kobayashi, Tokyo

T. Kobayashi, Tokyo

R. Lisk, Princeton, N.J.

L. Martini, Milan

S.M. McCann, Dallas, Tex.

$J$. Meites, East Lansing, Mich.

R.J. Reiter, San Antonio, Tex.

U. Scapagnini, Naples

V. Schreiber, Prague

S. Taleisnik, Cordoba

$N$. Winer, Lexington, kent.

S. Karger · Basel · München · Paris · London · New York · Sydney 


\section{Contents}

KaWAKami, M.; Terasawa, E.; Kimura, F. and WAKABAYAShi, K. (Yokohama):

Modulating Effect of Limbic Structures on Gonadotropin Release ....

REUTER, L.A. and LISK, R.D. (Princeton, N.J.): Progesterone-Sensitive Loci for

Blockade of Ovulation in the Hamster.

CARdinali, D.P.; HyYPPÄ, M.T. and Wurtman, R.J. (Cambridge, Mass.): Fate

of Intracisternally Injected Melatonin in the Rat Brain

SMith, E.R.; DomingueZ, R. and LeVINE, S. (Stanford, Calif.): Effects of Water

Restriction on Reproductive Function in Female Rats 41

NAGleR, J.; CONFORTI, N. and FELdman, S. (Jerusalem): Alterations Produced by Cortisol in the Spontaneous Activity and Responsiveness to Sensory Stimuli of Single Cells in the Tuberal Hypothalamus of the Rat ........................................ 52

Libertun, C.; Timiras, P.S. and Kragt, C.L. (San Francisco, Calif.): Sexual Differences in the Hypothalamic Cholinergic System before and after Puberty: Inductory Effect of Testosterone ............................................................................. 73

Blake, C.A.; Scaramuzzi, R.J.; Hilliard, Jessamine and SAWYer, C.H. (Long Beach, Calif.): Circulating Levels of Pituitary Gonadotrophins and Ovarian Steroids in Rats after Hypothalamic Deafferentation .............................................. 86

LYMANGROVER, J.R. and BRODISH, A. (Cincinnati, Ohio): Time-Course of Re sponse to Hypothalamic Extract and Multiple Use of Lesioned Rats for CRF Assay ..................................................................................................................... 98

NADLER, R.D. (Atlanta, Ga.): Further Evidence on the Intrahypothalamic Locus for Androgenization of Female Rats

CARrillo, A.J.; Kastin, A.J.; DunN, J.D. and Schally, A.V. (New Orleans, La.): MSH Activity in Plasma and Pituitaries of Rats with Large Hypothala

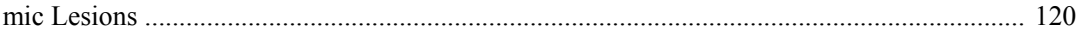

HeFFner, Linda J. and VAN TIEnHOVEn, A. (Ithaca, N. Y.): Effects of Proge sterone on Uptake and Retention of ${ }^{3} \mathrm{H}$-Testosterone in the Neonatal

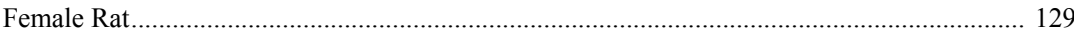

LiSK, R.D. and FERGUSON, D.S. (Princeton, N.J.): Neural Localization of EstrogenSensitive Sites for Inhibition of Ovulation in the Golden Hamster Meso-

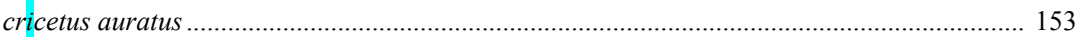

Mitchell, J.A.; Hutchins, M.; SChindleR, W.J. and CRгГCHLOW, V. (Houston, Tex.): Increases in Plasma Growth Hormone Concentration and NasoAnal Length in Rats Following Isolation of the Medial Basal Hypo thalamus 161

Miller, M. and WiLKS, J.W. (Kalamazoo, Mich.): Urinary Antidiuretic Hormone

Excretion During the Menstrual Cycle and Pregnancy in the Monkey 174

Stern, Judith M.; Goldman, L. and Levine, S. (Stanford, Calif.): PituitaryAdrenal Responsiveness during Lactation in Rats 
MORIN, L.P. (Newark, N.J.): Ovulatory and Body Weight Response of the Hamster to Constant Light or Pinealectomy......

Goldman, L; Winget, Constance; Hollingshead, G.W. and Levine, S. (Stan ford, Calif.): Postweaning Development of Negative Feedback in the Pituitary-Adrenal System of the Rat. 199

Silverman, AnN-Judith; VAala, Sharon S. and KNigge, K.M. (Rochester, N.Y.): Transport Capacity of Median Eminence. IV. In vivo Thyroxine Trans

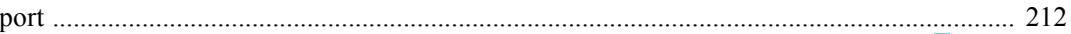

LyMANGROVER, J.R. and Brodish, A. (Cincinnati, Ohio): Tissue CRF: An ExtraHypothalamic Cortícotrophin Releasing Factor (CRF) in the Peripheral Blood of Stressed Rats .................................................................................................. 225

Portanova, R. and SAYers, G. (Cleveland, Ohio): An in vitro Assay for Corticotrophin Releasing Factor(s) using Suspensions of Isolated Pituitary

Cells ......................................................................................................................... 236

GAZIRI, L.C.J. and LADOSKY, W. (Parana): Monoamine Oxidase Variation during Sexual Differentiation

RAMALEY, Judith A. and BunN, E.L. (Bloomington, Ind.): Adrenal Function in Rats

Given PMS before Puberty: Serum Corticosterone Values.

Choudhury, S.A.R.; SHARPe, R.M. and Brown, P.S. (Bristol): Pituitary Follicle-

Stimulating Hormone Activity in Rats Treated with Apomorphine,

Pimozide and Drugs that Modify Catecholamine Levels ................................................... 272

BOUILlÉ, C. and BAYLÉ, J.D. (Montpellier): Effects of Hypothalamic Stimulation

on Pituitary-Adrenocortical Activity in Conscious Unrestrained Pigeons 284

OJEDA, S.R. and MCCANN, S.M. (Dallas, Tex.): Evidence for Participation of a

Catecholaminergic Mechanism in the Post-Castration Rise in Plasma

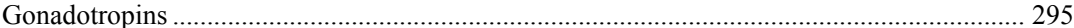

Kalra, SATyA P.; Krulich, L. and MCCANN, S.M. (Dallas, Tex.): Changes in Gonadotropin-Releasing Factor Content in the Rat Hypothalamus following Electrochemical Stimulation of Anterior Hypothalamic Area and during the Estrous Cycle .......................................................................................... 321

Redgate, E.S. and FAhringer, E.E. (Pittsburgh, Pa.): A Comparison of the Pitui tary Adrenal Activity Elicited by Electrical Stimulation of Preoptic, Amygdaloid and Hypothalamic Sites in the Rat Brain .......................................................... 334 Clabough, Jeanne W. and Norvell, J.E. (Richmond, Va.): Effects of Castration, Blinding, and the Pineal Gland on the Harderian Glands of the Male Golden Hamster................................................................................................................. 344

POMERANTZ, GIGI and SORRENTINO, S., Jr. (Rochester, N.Y.): The Influence of Melatonin Administered Subcutaneously, Intravenously, or Intraocularly upon Ovulation in the PMS-Treated Immature Rat................................................................ 354

ZÁrate, A.; CAnales, E.S.; Soria, J.; Maneiro, J.P. and MacGregor, C. (Mexico City): Effect of Acute Administration of L-Dopa on Serum Concentra tions of Follicle-Stimulating Hormone (FSH) and Luteinizíng Hormone $(\mathrm{LH})$ in Patients with the Amenorrhea-Galactorrhea Syndrome ............................................ 362

Short Communications

CSABA, G. and BARÁTH, P. (Budapest): Tritiated 5-Hydroxytryptamine Uptake of the Mast Cells in the Rat Thyroid Gland 


\section{Contents}

Shimada, K.; YANO, J.; Oshima, S. and Tonoue, T. (Nagoya, Japan): Effect of Photic Stimulation on Hypothalamic Electroencephalograph and Thyroid Activity in the Chicken ..................................................................................... 142 Tima, L.; Trentini, G.P. and Mess, B. (Pécs, Hungary): Effect of Serotonin on Ovulation Induced by Pinealectomy in Anovulatory Frontal-Deafferented Rats ................................................................................................................ 149

Hiroshige, T. and WADA-OKADA, S. (Sapporo): Diurnal Changes of Hypothalamic Content of Corticotropin-Releasing Activity in Female Rats at Various Stages of the Estrous Cycle................................................................................... 316 Lybeck, H.; Leppäluoto, J.; VirkKunen, P.; Schafer, D.; CARlsson, L. and MULDER, J. (Malmö): Suppression of TRH-Mediated Thyroidal Release of ${ }^{131}$ I by a Synthetic Analog .......................................................................................... 366

Pavel, S.; Mätrescu, Liana and Petrescu, Magdalena (Bucharest): Central Corticotropin Inhibition by Arginine Vasotocin in the Mouse .............................................. 371

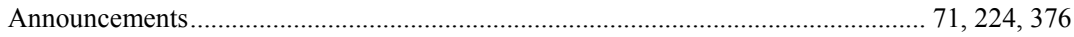

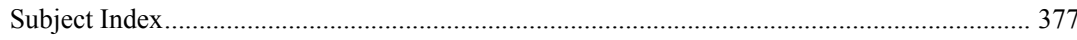

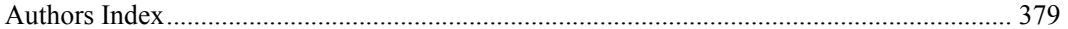

